\title{
Workshop Pemulasaran Jenazah
}

\author{
${ }^{1 *}$ Muhammad Jundullah, ${ }^{2}$ Marimin, ${ }^{3}$ Muhaimin, ${ }^{4}$ Umar Tauhid, ${ }^{5}$ Wibowo, ${ }^{6}$ Yulianta \\ STIE Hidayatullah, Depok, Jawa Barat, Indonesia \\ *umar.tauhid@stiehidayatullah.ac.id
}

\begin{abstract}
Abstrak
Tujuan Pengabdian Kepada Masyarakat (PKM) Mahasiswa ini adalah untuk memberikan edukasi kepada masyarakat tentang bagaimana pemulasaran jenazah yang sesuai dengan ketentuan yang berlaku. Masih sangat sedikit dan jarang di masyarakat pengetahuan tentang bagaimana mengurus jenazah dengan baik sesuai dengan ketentuan Islam. Seringkali masyarakat memanggil pihak tertentu yntuk mengurusi jenazah di lingkungan sekitarnya. Oleh karena itu, kegiatan ini dilakukan agar setiap pengurus mesjid atau mushola memiliki kemampuan untuk mengurus jenazah secara mandir dengan baik dan benar.
\end{abstract}

Kata Kunci: Pendidikan, Mesjid, Jenazah

\begin{abstract}
The goal of this devotion to social community by college student is to provide education to the public about how to dispose of corpses in accordance with applicable regulations. There is still very little and rare knowledge in the community about how to properly care for the corpse in accordance with Islamic provisions. Often people call certain parties to take care of corpses in the surrounding environment. Therefore, this activity is carried out so that every administrator of the mosque or prayer room has the ability to take care of the corpse independently and properly.
\end{abstract}

Keywords: Education, Mosque, Corpse

\section{PENDAHULUAN}

Salah satu kewajiban Muslim terhadap muslim lainnya adalah mengurus muslim tersebut jika ia telah meninggal dunia, dalam hal ini adalah memperlakukan jenazah sebagaimana aturan yang terdapat dalam fikih Islam. Walaupun kewajiban itu dikategorikan sebagai kewajiban yang bersifat fardhu kifayah, namun kemampuan untuk mengurus jenazah sudah menjadi kebutuhan tersendiri bagi masyarakat muslim. Terlebih di negara dengan budaya saling asuh yang begitu lekat di Indonesia.

Pengurusan jenazah seringkali dilakukan oleh pihak pengelola mesjid karena salah satu hak jenazah adalah disolati sebelum dikuburkan atau dimakamkan. Namun demikian, sangat sedikit pengelola mesjid yang memiliki pemahaman dan kemampuan untuk mengurus jenazah mulai dari A sampai Z. hal ini dapat dilihat dari permintaan yang banyak akan tim pemulasaran jika terjadi kematian di suatu tempat.

Berangkat dari fenomena tersebut, kami tergerak untuk melakukan pendidikan dan penyuluhan tentang bagaimana melakukan pemulasaran yang baik dan benar sesuai dengan tuntunan Islam.

\section{METODE}

Metode pelaksanaan pengabdian kepada masyarakat ini diawali dengan melakukan peninjauan lapangan dan koordinasi dengan mitra. Metode kegiatan ini adalah mendatangi dan memberikan pelatihan dan diskusi pentingnya menguasai cara memulasarkan jenazah dengan baik. Kami memberikan presentasi terlebih dahulu berdasarkan kitab Kifaayatul Khyaar kemudian dilanjutkan dengan praktek langsung. 


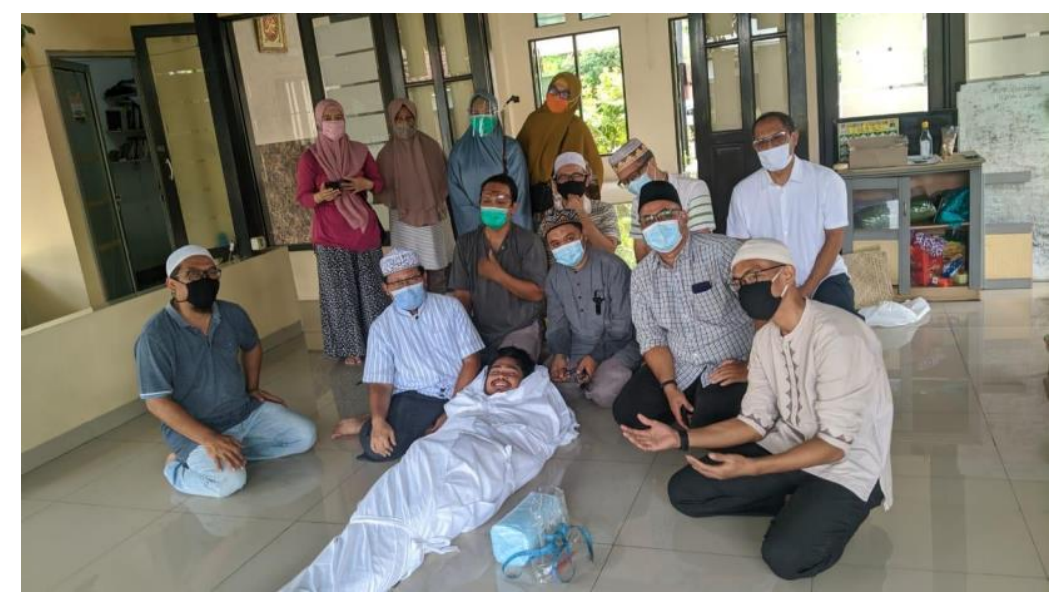

Gambar 1. Pelaksanaan Kegiatan PKM dilokasi

\section{HASIL DAN PEMBAHASAN}

Lazimnya, pengurus mushola dan mesjid di masyarakat berasal dari kalangan umum yang secara sukarela menghibahkan dirinya untuk mengelola mesjid atau mushola. Sehingga kemampuan agamanya jauh dari pemahaman lulusan pesantren atau sekolah agama lainnya. Hal ini kerap kali menjadi alasan besar mengapa
mesjid dan mushola kerap memanggil tim diluar
pengurus untuk menangani jenazah jika di
wilayah sekitarnya ada kematian warga.
Kegiatan ini disambut baik oleh pengurus
atau pengelola mesjid. Sentuhan akademisi
mampu memberi warna dan sudut pandang yang
berbeda. Dengan pemaparan dan diskusi serta
memberi dorongan semangat masyarakat untuk
mengetahui lebih banyak manfaat akan suatu
pemahaman dalam mengurus jenazah.
Masyarakat bukan saja senang, namun lebih dari itu sebagai sebuah bentuk kegiatan yang meningkatkan skill dan pemahaman mereka yang sangat dibutuhkan bagi kehidupan bermasayrakat. dengan adanya kegiatan ini pengurus mesjid jadi lebih mengetahui dapat mandiri dalam mengurus jenazah.

Kegiatan dilakukan dengan dilengkapi pendampingan apabila ada jenazah yang diurus oleh pengelola mesjid. Dengan demikian, lepas dari pendampingan pengurus mesjid dapat dengan sendirinya mengurus jenazah tanpa perlu memanggil dan membayar pihak lain. 


\section{PENUTUP}

\section{KESIMPULAN}

Setelah dilakukannya kegiatan ini, mesjid/ mushola tempat kami mengabdi tidak lagi menggunakan jasa pihak ketiga untuk mengurus atau memulasarkan jenazah. Dari aspek manajemen, hal ini mampu mereduksi biaya atau anggaran mesjid dan tentu saja meningkatkan image mesjid atau mushola di mata masyarakat dalam hal pelayanan sosial.

\section{SARAN}

Saran dari kami agar kegiatan ini dapat diduplikasi di mesjid atau tempat lain, sehingga manfaat yang didapatkan menjadi lebih luas dan multiplier effect nya dirasakan masyarakat.

\section{DAFTAR PUSTAKA}

Abi Bakar bin Muhammad Husein, Imam Taqiyuddin. (1995). Kifayah al-Akhyar Fi Halli Gayatil Ikhtiyar. Beirut: Dar al-Kitab al-Ilmiyah

Majelis Upaya Kesehatan Islam Seluruh Indonesia (MUKISI). (2017). Pedoman Standar Pelayanan Minimal Rumah Sakit Syariah dan Indikator Mutu Wajib Syariah. Jakarta: MUKISI

Murtiningsih. (2019). Seminar Dan Workshop Pemenuhan Kebutuhan Spiritual Pasien Menjelang Ajal Dan Pengurusan Jenazah. Jurnal Abdimas Kesehatan, vol 1(3).

Nurhayati, N., et al. (2020). Pemberdayaan Pengelolaan Keuangan Dalam Meningkatkan Kemampuan Manajerial Bagi Pelaku Usaha Di Desa Warnasari Kecamatan Pangalengan Kabupaten Bandung. Kaibon Abhinaya: Jurnal Pengabdian Masyarakat, 2(2), 66-70. 